\title{
The Effect of Proactive Personality on the Relationship Between Emotional Intelligence and Burnout Syndrome: A Case Study on Academic Staff Working in Public Universities of Aegean and Central Anatolia Regions
}

\author{
Melahat ÖNEREN ${ }^{i D}{ }^{a}$ Nurcan ÇETINER ${ }^{i}{ }^{b}$ Tayfun ARAR ${ }^{i}{ }^{c}$ Gülșen YURDAKUL ${ }^{i D} d$ \\ aKırıkkale University, Business Department, Kirikkale, Turkey. melahatoneren@mynet.com \\ bKaramanoglu Mehmetbey University, Office Services and Secretary Dept., Karaman, Turkey. nurcancetiner@kmu.edu.tr \\ c Kirıkkale University, Business Department, Kirikkale, Turkey.tayfunarar@kku.edu.tr \\ d Kirıkkale University, Business Department, Kirikkale, Turkey. gulsen.yurdakul10@gmail.com
}

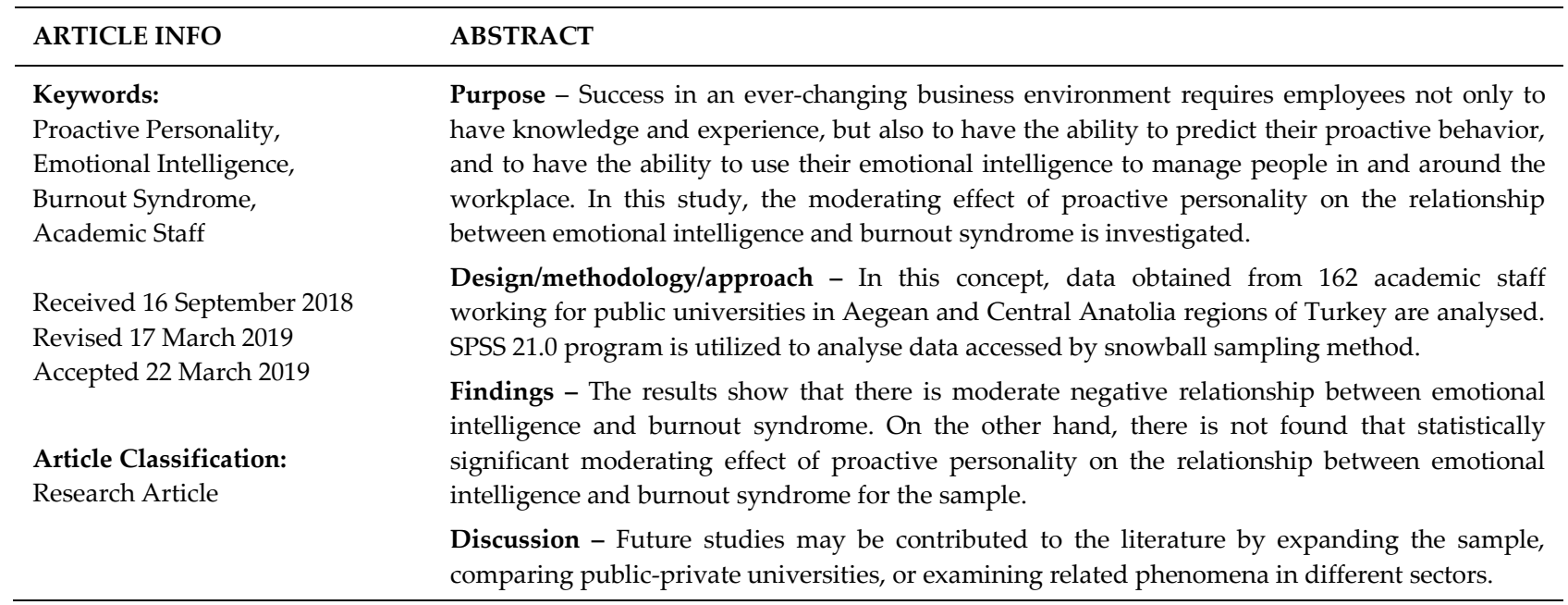

\section{I.Introduction}

In the developing and ever-changing world, the secret of success that is accepted by experts not only to have knowledge and experience, but also to be able to take advantage of the emotional intelligence of employees and to be able to manipulate people in the workplace and around them (Weisinger, 1998, p. 7, Koçyiğit, 2016, p. 214, Herece and Şener, 2017p. 40). Studies on emotional intelligence have been increasing in recent years after the conclusion that the use of emotions is important to be successful in business life.

In the rapidly flowing and exhausting life of the modern age, people find themselves in complex relationships and face problems expressing their feelings.In this case, the happiness of the individuals can only be achieved by attaining fulfillment in spiritual and emotional terms. The use of emotional intelligence skills helps individuals and the community to increase communication power and, in this case, to make individuals happier (Somuncuoğlu, 2005, p. 274). High emotional intelligence skills also affect professional life, enabling individuals to communicate effectively with their colleagues and having effective management skills contribute to their success in the working life (Maboçoğlu, 2006, p. 15). Individuals with high emotional intelligence can cope with negative emotions such as burnout, stress, and anger. On the other hand, individuals with low level of emotional intelligence are more likely to experience burnout at work because of low level internal motivation (Herece and Şener, 2017, p. 40).

Burnout (Schwartzhoffer, 2009, p. 4);is the adverse behavioral attitudinal and physical changes that people experience in response to extreme stress. Burnout, which is comprised of three steps those are emotional exhaustion, desensitization and decrease in personal performance (Schwartzhoffer, 2009, p.4, Göktepe, 2016, p. 29, Iraz and Ganiyusufoglu, 2011, p. 452), causes people to feel inadequate in their work relations and 


\section{M. Öneren - N. Çetiner - T. Arar - G. Yurdakul 11/1 (2019) 575-586}

social relationships with their surroundings. Cited from Leiter's study in 1991, Yürür (2011, p. 112) suggests that individuals who demonstrate proactive behavior in combat with difficult situations encountered in the workplace, where the ability to cope with difficult conditions affects burnout levels, are less likely to burnout.

Besides today, because the change is continuous and the uncertainties around the organization increase as a result of the changes experienced, the organizations need employees who can take responsibility by using the initiative in order to maintain their presence in an increasing competition environment, are open to innovation, and can take measures in advance and determine the developments in the environment (Uncuoğlu Yolcu and Çakmak, 2017: 426).Individuals with proactive personality are people who are in peace with themselves and their environment, with a positive thought-provoking solution that is able to use their emotional and spiritual intelligence with a fine harmonious analysis of events that develop beyond the control of themselves. Individuals who have proactive personality collect information before events occur, think, analyze, make decisions, prepare plans and implement them. They are self-confident and have initiative (Eren, 2018, p. 1).

The academician is the experienced person who has extensive knowledge, wide horizon, and works for the development of the society.It is the expectation of self-educated intellectual academicians in the field that the problem of the world in the community and the broader framework is to be holistically approaching the events, analyzing the facts and problems in a meaningful way and evaluating them in the scientific framework and producing solutions. From this point of view, academicians as life missionaires, have made it their duty to create innovations, enlight their environments and anticipate the future (Ortaş, 2004, p. 1112). According to Karaçay and Mihçı (1999, p. 301-302); an academician should have the following characteristics as questioning, realizing the learning, researching and teaching actions, always keeping the enthusiasm of the research excitement and should be a free and original thinker. Similarly Doctoral Instructor Murat Aktan's personality traits for academic career according to his work carried out by academic staff with different titles working in 342 different disciplines by internet questionnaire at www.akademikpersonel.org in 2014, to value knowledge, to express ideas freely, to be objective, willing, enthusiastic, reliable, analytical, critical, creative, disciplined, open to innovation, with internal motivation, outward looking, understanding, regular, calm, joyful, to be able to communicate with people, to able to make long-term planning, to influence others in what he believes, and to anticipate future opportunities and problems.

Academicians should have high level of emotional intelligence. They should be aware of themselves well, regulate their own feelings, have high motivation, understand others with emphaty, have social skills such as communication, cooperation and teamwork (Karadeniz, 2017, p. 4). They can become more productive and effective at what they do by motivating themselves if only when they use their emotional intelligence. By empathizing with the environment, they can more easily determine what others need and are more successful in their research (Goleman, 1998, p. 61-62). In addition, academicians with high emotional intelligence will have the ability to cope with negative emotions such as burnout and stress.As indicated by Güllüce and İşcan (2010) study, it is seen that individuals with emotional intelligence can cope with burnout.The responsibilities of the academicians cannot be denied in the work done to access the information, to foresee social problems and to produce solutions. The fact that there is a burnout academic will not provide an effective development in terms of sociology. The academicians, who have such broad responsibilities, will be able to better analyze their social situations by using the proactive personality traits that we can associate with their predisposing characteristics.They will be able to observe the positive / negative situations that may occur in the future and to produce clearer solutions against these situations and thus they will achieve high success in their studies.

In this study, the question to be answered is whether academicians who have proactive personalities are much emotionally burnout because of the intention of deciding by anticipating everything beforehand which result in self-consuming even if they have high level of emotional intelligence. For this purpose, firstly literature search is made and basic concepts are explained, research model and hypothesis are presented. By analyzing the research findings, the significance of the results obtained is discussed. 


\section{Conceptual Framework}

\section{Proactive Personality}

The word proactive; according to Cambridge Learner's Dictionary (2018); is taking precautions by making changes before time; it means to act in advance. Proactivity is defined as the ability to act in anticipation of future problems, needs, or changes, suggests a forward-looking perspective with innovative or new initiative activity (Lumpkin and Dess, 1996, p. 146).According to the theoreticians working on psychology and organizational behavior, human environment and behavior are constantly affecting each other (Çetin and Basim, 2013, p. 96). The humanbeing is not a passive receiever of environmental pressures, but has an influence on the environment. Proactive behavior is the whole set of behaviors that both develop depending on individual and situational factors as in any behavioral concept and change people's immediate environment and situations which people are supposed to be proactive. For another definition according to Crant (2000: 436), proactive behavior is to take the initiative to improve the current situation or to create new ones and to force the status quo rather than to passively adapt to the current situation.The reason why people make proactive behavior is the need for people to manipulate and control the environment (Bateman and Crant, 1993, p. 104).Individuals with proactive personality are also the first to assess new opportunities by perceiving what is needed to achieve their goals and make success (Lee and Peterson, 2000, p. 406). They search for opportunities, act on an initiative and continue to work until reaching the goal by keeping up with the change (Bateman and Crant, 1993, p. 105). Proactive people can recognize opportunities ahead of time, and are entrepreneurs and can lead themselves to work decisively to achieve the goals they have identified.Proactive individuals are the ones who initiate actions themselves by using their own initiatives, would like to influence their environment by using the opportunities in the environment and using them (Çetin and Varoğlu, 2009: 57).Individuals with a proactive personality are active instead of being passive in the face of events (Çelik and Topçuoğlu, 2017: 1225). They exhibit high performance in work environments tend to focus on solutions when they encounter problems. Furthermore they are sensitive to their environment and can take responsibility in both business and social circles (Büyükgöze and Gelbal, 2016, p. 92).

Organizations expect their employees to use their personal initiatives to increase organizational effectiveness, overcome problems, deal with challenges and to use their personal initiatives characterized by being proactive to find alternative ways of doing business (Frese, Kring, Soose and Zempel, 1996: 38-39).

\section{Emotional Intelligence}

Emotional intelligence is the use of emotions in the desired direction to achieve the intended goals. It is people's trying to direct their behaviors from their own emotions to obtain positive results which is in short, the wise use of emotions (Weisinger, 1998, p. 7-12). Emotional intelligence is the ability to recognize, understand and use one's feelings effectively; it helps the person to cope with both himself and the people around him (Herece and Şener, 2017, p. 40).Emotional intelligence according to Salovey and Mayer, by whom first introduced to the literature (Weisinger, 1998, p. 13; Mete and Akpinar, 2013, p. 76), is subset of social intelligence and that includes the ability to monitor the feelings of one's own and / or others, to choose within these feelings, and to use this knowledge to guide one's thinking and actions(Salovey and Mayer, 1990, p. 189).Individuals who have high level of emotional intelligence can understand and appreciate individual needs, needs, strengths and weaknesses and feelings and can reach their goals much more quickly and easily than those who have difficulty in communicating non-socially (Herece and Şener, 2017, p. 40). People who have developed skills related to emotional intelligence are aware of their emotions and can manage them as a form of response to an encounter (Koçyiğit, 2016, p. 211).Not only solutions can be created both to personal problems and to others' problems (Weisinger, 1998, p. 13); but also they can understand and express their own feelings, recognize and regulate their emotions, and use their feelings to motivate adaptive behaviors.Individuals with emotional intelligence are individuals who take action (Salovey and Mayer, 1990, p. 200).There are sub-dimensions that form the basic structure of the concept of emotional intelligence. These are self-awareness, managing emotions, self-motivation, developing interpersonal relationships, developing effective communication skills, and encouraging others to help themselves (Weisinger, 1998). Salovey and Mayer (1990) classify the extent of emotional intelligence as emotional evaluation and expression, emotion regulation and emotion usage, as indicated in Table-1. Cited from Mayer and Salovey's study in 1997, 
Salovey and Grewal (2005, p. 281) reported that in Mayer and Salovey's 1997 study, sub-dimensions of emotional intelligence were re-modeled as perceiving emotions, using emotions, understanding emotions and managing emotions. Gürbüz (2004) decides these dimensions as self-consciousness, self-esteem, management of emotions, self motivation / enthusiasm and managing empathy and relationships.

Table 1. Conceptualization of Emotional Intelligence

\begin{tabular}{|c|c|c|c|c|c|}
\hline \multicolumn{6}{|c|}{ EMOTIONAL INTELLIGENCE } \\
\hline \multicolumn{3}{|c|}{ Evaluation and Expression of Emotion } & \multicolumn{2}{|c|}{ Emotion Regulation } & \multirow{3}{*}{$\begin{array}{ll} & \text { Emotion Usage } \\
\text { - } & \text { Flexible Planning } \\
\text { - } & \text { Creative Thinking }\end{array}$} \\
\hline \multicolumn{2}{|c|}{ Self } & Other & In self & Other & \\
\hline Verbal & $\begin{array}{l}\text { Non- } \\
\text { Verbal }\end{array}$ & $\begin{array}{l}\text { Non- } \sqrt{\text { erbal }} \quad \text { Empathy } \\
\text { Perception }\end{array}$ & & & \\
\hline & & & & & $\begin{array}{l}\text { - Directed Attention } \\
\text { - Motivation }\end{array}$ \\
\hline
\end{tabular}

Emotional intelligence is an upgradeable feature (Weisinger, 1998, p. 21), which affects people to be successful in their personal and professional lives (Weisinger, 1998, p. 7, Mete and Akpinar, 2013, p. 77).People with high emotional intelligence have the ability to cope with negative emotions such as exhaustion and stress. People with low emotional intelligence are more likely to experience burnout because their inner motivations are also at a low level. They also feel insecure in the face of events, seek ways to escape their emotions, empathize with their environment and become increasingly insensitive (Herece and Şener, 2017, p. 40).

\section{Burnout Syndrome}

Burnoutisthe negative behavioral, attitudinal and physical changes of workers as a result of excessive work stress (Schwartzhoffer, 2009, p. 4). Burnout (Göktepe, 2016, p. 27), is a concept that has physical and psychological dimensions that arise from employees' desire to escape from work psychologically due to work stress, decrease in the quality of service offered and loss of motivation.Burnout, which is often replaced by work stress, differs from that concept in a variety of forms and is a consequence of long-term job stress (Schwartzhoffer, 2009, p. 3).Burnout is a process that affects the attitudes, perceptions, and judgments of a person over time (Freudenberger, 2012, p. 247), which arise from the depletion of the resultant energy that the individual struggles with many of the business-related problems.

Burnout syndrome is a condition in daily routine or business life. The loss of interest, which is the result of the performance seen during the day or the decrease in the performance seen in business life, is a sneaky slowly growing psychological situation involving exhaustion feelings (Göktepe, 2016, p. 21).Burnout manifests itself in various symptoms in terms of physical, mental, behavioral, and emotional.The burnout syndrome refers to the fact that one feels continuously experiencing emotional, mental and physical energy loss (Freudenberger, 2012, p. 247), finding every activity boring and dissatisfied, reluctance to go to work in the morning, frustration, hostility and negative feelings, a decrease in attention and concentration characteristics due to the experienced work stress, a decrease in work performance, problems with people at home and at work, not taking care of self, and being busy with work even is spare time(Göktepe, 2016, p. 2122).Insomnia, chronic fatigue, common cold, flu; (Schwartzhoffer, 2009, p. 4), weight gain or weight loss, the onset and increase in the use of drugs, cigarettes and alcohol (Candan and İnce, 2014, p. 64), back or waist pain, acne, rash, eczema, and skin problems (Freudenberger, 2012, p. 247) are the main symptoms of burnout syndrome.

Burnout syndrome consists of three sub-dimensions, emotional and physical exhaustion, depersonalization and reduction of personal achievement (Schwartzhoffer, 2009, p. 4, Göktepe, 2016, p. 29).The person who is in the dimension of emotional and physical exhaustion feels exhausted and faces negative feelings such as excessive fatigue, chronic headache, stomach and digestive disorders, collapsed emotional public, hopelessness, and discomfort. Burnout syndrome is experienced internally on the decline of personal success. One feels as an unsuccessful, unproductive, inadequate individual by adopting the feelings of inattention and failure. In the dimension of desensitization; there are negative and extreme disconnected situations in human relations. The burnout syndromeinsensitive person in the living environment does not fulfill his responsibilities, is closed to the division of labor, remains insensitive to the increase of the 
workload of the colleagues (Göktepe, 2016, p. 29), puts a distance between them and shows negative behaviors and feelings towards them (Candan and İnce, 2014, p. 63).

Göktepe (2016, p. 29-31), cited from Maslach, lists the reasons for the burnout syndrome as the causes originating from the working life and originating from the individual.Among the causes of work life; there is workload that one has problem with because of the uncertainity in job description and transends the one's capacity, control areawhich describes whether the employee has freedom in decision making in working area, whether the employee has no right to say "no" because of constant orders from the supervisor. Another reason is reward fieldthat is about if the employee cannot receive salaries or bonuses depending on the performance shown, and that he feels that he is inadequately charged and makes himself feel as a worthless and useless individual.In the field of affiliation; there are problems in human relations, use of negative communication patterns, troubles caused by mobbing, problems arising from administrators making favoritism in transferring authority. Another reason is that the employee thinks that he has been treated unfairly and that it causes resistance and conflicts to take place. In the field of values; the incompatibility of employees' personal characteristics with the vision and mission of the institution they are working with can be listed as the reasons arising from working life.The reasons connected to the individual causing the burnout are; the feeling of having neurotic personality traits (waiting for extreme compassion, unable to focus, insecurity, unable to plan), having an anxious personality, low self esteem, dissatisfaction with career, high expectation of family and social environment, and not to be able tospend enough time with the family. Situations such as role conflict, role ambiguity and overloading of the person in the occupations where communication with the people is important can also cause exhaustion in working life (Candan and İnce, 2014, p. 63).

\section{III.Literature Review}

In literature there are some studies investigated the relationship between emotional intelligence and burnout at different sectors such as health, education and other public ones. For example, Cofer et al. (2018) and Beierle et al. (2018) investigated if burnout is related with emotional intelligence. The results of the studies which are conducted with surgical residents show that there is a negative relationship between these two concepts. Similarly with the same purpose and sector, Pérez-Fuentes et al. (2019) found the same way relationship between emotional intelligence and burnout in their study conducted with nurses. Chan (2006) and Platsidou (2010) also found the same relationship in their studies conducted with Chinese secondary school teachers and Greek education teachers respectively.According to Goren (2018) an employee or a team may prevent burnout by building up the emotional intelligence with ten strategies such as; expliciting one's intention for the present day, attaching importance on self-care, paying attention to emotions, thinking twice before responding at stressful time, keeping curiousity, creating places for all kind of emotions, noticing the people around, making connections with people, not being ashamed of apologizing if necessary, beginning and ending the day happily with staff.

Though there is not any study found that analyzes the role of proactive personality in this relation. With a different dependent variable, in Jafri et al.'s (2016) study it is analyzed that the moderating role of proactive personality in the relationship between emotional intelligence and employee creativity. According to the study practiced in two public corporations operating in Bhutan, proactive personality moderates in a positive way the relationship between emotional intelligence and creativity. Moreover, with a different independent variable, in Alarcon's (2009) study, it is found that proactive personality yields significant relationship with burnout.

On the other hand, in the national literature, the studies related to this paper's topic is very few. In Herece and Şener's study (2017), which is mainly about to find whether there are any effects of sub-dimensions of emotional intelligence on the sub-dimensions of burnout in civil servants, it is also studied that if the emotional intelligence and burnout levels of employees differ from genders and occupational features. It is found that there is not a significant difference in emotional intelligence of employeesamong genders, but a significant difference in occupational features. It is also found that there are significant and positive effects of two of the sub-dimensions of emotional intelligence which are optimism and usage of emotions on the one of the sub-dimensions of burnout that is individual success feeling. In Güllüce and Isşcan's study (2010) with the topic of the relationship between occupational burnout and emotional intelligence, it is found that there 
is a negative relationship between these two concepts among the managers. In Candan's (2016) study with the topic of the relationship among job embeddedness, performance and burnout, it is found that academicians have burnout below the average, positive relationship between society related embeddedness and performance and a negative relationship between organization related embeddedness and burnout. In Öztürk's study (2006) there is a significant relationship among burnout, job satisfaction and emotional intelligence in pre-school teachers.

Literature review showed that there is non research that studied whether the proactive personality has effect on the relationship between emotional intelligence and burnout. This research aims to fill a gap in this area that exists in Turkey and to contribute to theliterature.

\section{IV.Methodology}

The main purpose of this study is by examining the concepts of proactive personality, emotional intelligence and burnout syndrome theoretically, to investigate the effect of proactive personality on the relationship between emotional intelligence and burnout. The final model of the research is seen in Figure 1.

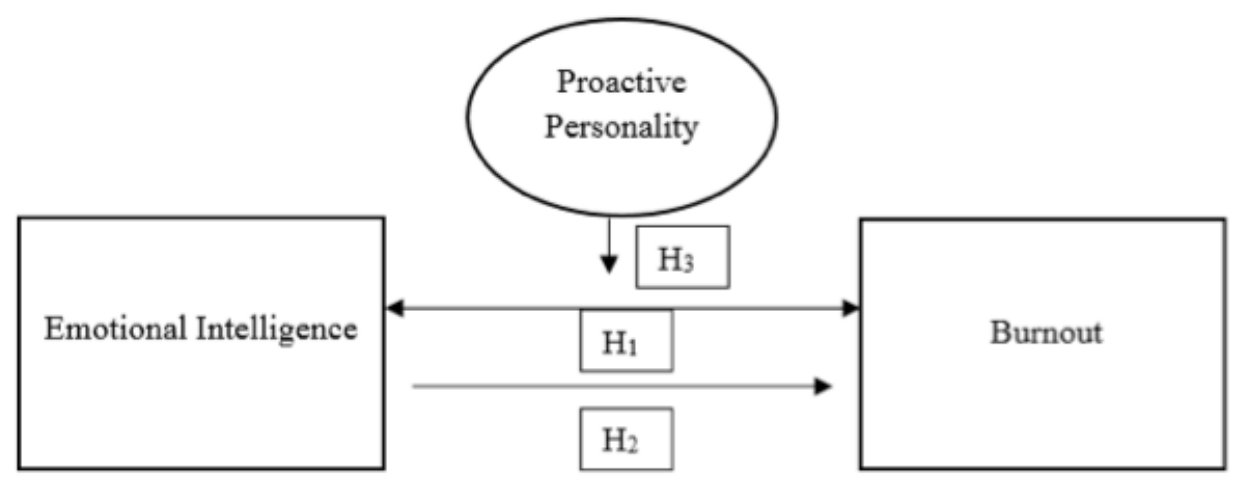

Figure 1. The Model of the Study

According to the model, the hyphotheses are as follows:

$\mathrm{H}_{1}$ : There is a significant negative relationship between emotional intelligence and burnout in academic staff.

$\mathrm{H}_{2}$ : There is a significant effect of emotional intelligence on burnout in academic staff.

$\mathrm{H}_{3}$ : There is a moderating effect of proactive personality on the relationship between emotional intelligence and burnout in academic staff.

In the research, the conceptual framework was searched and the model of the research is decided asthe relational screening model. The questionnaire was applied as a data obtaining tool. A total of 182 units were returned from the academic personnel who were reached through the snowball sampling method in public universities in Aegean and Central Anatolia regions. One-Sample Kolmogorov-Smirnov test was performed and 20 questionnaires were determined to be unsuitable for analysis, and the return rate was $89 \%(\mathrm{n}=162)$ as shown in Table 2 and normality was provided for each variable (sig Emotional_Intelligence =,356;sigBurnout $=, 714$;sigProactive_Personality $=, 069>0,05)$.

Table 2. Normality Test Results

\begin{tabular}{|c|c|c|c|c|}
\hline & & $\begin{array}{c}\text { Emotional } \\
\text { IntelligenceMean }\end{array}$ & $\begin{array}{c}\text { Proactive } \\
\text { PersonalityMean }\end{array}$ & $\begin{array}{c}\text { Burnout } \\
\text { Mean }\end{array}$ \\
\hline \multicolumn{2}{|l|}{$\mathrm{N}$} & 162 & 162 & 162 \\
\hline \multirow{3}{*}{ Normal Parameters } & Mean & 3.9365 & 4.0549 & 2.1041 \\
\hline & Std. Dev. & .37708 & .41569 & .51934 \\
\hline & Absolute & .073 & .102 & .055 \\
\hline \multirow{2}{*}{ Most Extreme Differences } & Positive & .069 & .102 & .055 \\
\hline & Negative & -.073 & -.072 & -.045 \\
\hline \multicolumn{2}{|c|}{ Kolmogorov-Smirnov Z } & .928 & 1.298 & .698 \\
\hline \multicolumn{2}{|c|}{ Asymp. Sig. (2-tailed) (p) } & .356 & .069 & .714 \\
\hline
\end{tabular}


The questionnaire is composed of "The Emotional Intelligence Scale"which is developed by Bar-on in 2000 and translated into Turkish by Karamustafa (2016), "Maslach Burnout Scale" which is developed by Maslach and Jackson in 1981 and adapted to Turkish by Ergin (1992) and"Proactive Personality Scale" which is developed by Bateman and Crant (1993) and adapted by Akin, Abac1, Kaya and Aricı (2011) to 10 questions. Questionnaire items were measured with 5 scales of Likert.

\section{Results}

There are reliability and validity analyses results in Table 3. While in analyzing reliability of scales, Cronbach's Alphas are checked, for validity of scales, factor analysis is used.

Table 3. Reliability and Validity Results of Variables

\begin{tabular}{lcccc}
\hline \multicolumn{1}{c}{ Variable } & $\begin{array}{c}\text { KMO Scale } \\
\text { Validity }\end{array}$ & $\begin{array}{c}\text { Explained } \\
\text { Variance } \\
\text { \% }\end{array}$ & P value & Cronbach's Alpha $(\alpha)$ \\
\hline $\begin{array}{l}\text { Proactive } \\
\text { Personality }\end{array}$ & .773 & 63.526 & .000 & .747 \\
\hline $\begin{array}{l}\text { Emotional } \\
\text { Intelligence }\end{array}$ & .737 & 59.311 & .000 & .788 \\
\hline Burnout & .838 & 60.900 & .000 & .870 \\
\hline
\end{tabular}

As results show that while the Kaiser-Mayer-Orkin (KMO) values are .773, .737 and .838; total explained variances are $63.526 \%, 59.311 \%$ and $60.900 \%$ for Proactive Personality Scale, Emotional Intelligence Scale and Burnout Scale respectively. The results also show that Cronbach's Alpha reliability values are .747, 788 and .870 for scales in same order. According to Akgül ve Çevik (2005, p. 435), if Cronbach's Alpha value range is $0.00 \leq \alpha<0.40$, the scale is not reliable, $0.40 \leq \alpha<0.60$, the scale is low reliability, $0.60 \leq \alpha<0.80$, the scale is quite reliable, $0.80 \leq \alpha<1.00$ is reliable measure at high scale. In the light of this information it can be said that all scales are quite reliable.

Distribution of the demographic characteristics of the academic staff participating in the study according to the variables is shown in Table 4.

Table 4. Demographic Characteristics of Participants

\begin{tabular}{|c|c|c|c|c|c|}
\hline Variables & Categories & $\mathbf{n}$ & Total & $\%$ & Total \\
\hline \multirow{2}{*}{ Gender } & Female & 82 & \multirow[b]{2}{*}{162} & 50.6 & \multirow{2}{*}{100} \\
\hline & Male & 80 & & 49.4 & \\
\hline \multirow{4}{*}{ Age } & 29 and below & 57 & \multirow{4}{*}{162} & 35.2 & \multirow{4}{*}{100} \\
\hline & $30-39$ & 67 & & 41.4 & \\
\hline & $40-49$ & 29 & & 17.9 & \\
\hline & 50 and above & 9 & & 5.6 & \\
\hline \multirow{4}{*}{ Working Period } & 5 years and below & 33 & \multirow{4}{*}{162} & 20.4 & \multirow{4}{*}{100} \\
\hline & $6-10$ years & 31 & & 19.1 & \\
\hline & $11-15$ years & 11 & & 6.8 & \\
\hline & 16 years and above & 87 & & 53.7 & \\
\hline \multirow{5}{*}{ Academic Title } & Research Asst. & 36 & \multirow{5}{*}{162} & 22.2 & \multirow{5}{*}{100} \\
\hline & Lecturer & 34 & & 21.0 & \\
\hline & Dr. Lecturer & 20 & & 12.3 & \\
\hline & Assoc. Prof. & 8 & & 4.9 & \\
\hline & Prof. Dr. & 64 & & 39.5 & \\
\hline
\end{tabular}

$50.6 \%$ of the participants are females and $49.4 \%$ are males. $35.2 \%$ are under 29 years old, $41.4 \%$ are between 30 and 39 years old, $17.9 \%$ are between 40 and 49 years old and $5.6 \%$ are over 50 years old. When the working periods are examined; $20.4 \%$ have been working for 5 years and 6 years, $19.1 \%$ have worked for 6 10 years, $6.8 \%$ have worked for $11-15$ years and the remaining $53.7 \%$ have worked for 16 years. When the academic titles of the participants were examined, it was seen that $22.2 \%$ were research assistants, $21 \%$ were lecturers, $12.3 \%$ were doctoral lecturers, $4.9 \%$ were associated professors and $39.5 \%$ were professors. 
M. Öneren - N. Çetiner - T. Arar - G. Yurdakul 11/1 (2019) 575-586

Table 5. Correlation Results of Emotional Intelligence and Burnout of Academic Staff

\begin{tabular}{ccccc}
\hline & & EI & PP & BS \\
\hline \multirow{3}{*}{ Emotional Intelligence } & Pearson Korelasyon & 1 & $.442^{* *}$ & $-.413^{* *}$ \\
& Sig. (2-tailed) & & .000 & .000 \\
& $\mathrm{~N}$ & 162 & 162 & 162 \\
\hline \multirow{3}{*}{ Proactive Personality } & Pearson Korelasyon & $.442^{* *}$ & 1 & $-.225^{* *}$ \\
& Sig. (2-tailed) & .000 & & .004 \\
& $\mathrm{~N}$ & 162 & 162 & 162 \\
\hline \multirow{3}{*}{ Burnout Syndrome } & Pearson Korelasyon & $-.413^{* *}$ & -.225 & 1 \\
& Sig. (2-tailed) & .000 & .004 & \\
& $\mathrm{~N}$ & 162 & 162 & 162 \\
\hline
\end{tabular}

$\mathrm{EI}^{1}=$ Emotional Intelligence, $\mathrm{PP}^{2}=$ Proactive Personality, $\mathrm{BS}^{3}=$ Burnout Syndrome

**. Correlation is significant at 0.01 level (2-tailed).

As publiced in Table 5, there is significant moderate negative relationship between the levels of emotional intelligence and burnout of academic staff $(\mathrm{r}=, 413 ; \mathrm{sig}=, 000)$. This result supplies the first hypothesis.

Table 6. The Effect of Emotional Intelligence on Burnout

\begin{tabular}{llccccc}
\hline \multicolumn{1}{c}{ Model } & \multicolumn{2}{c}{$\begin{array}{c}\text { Unstandardized } \\
\text { Coefficients }\end{array}$} & $\begin{array}{c}\text { Standardized } \\
\text { Coefficients }\end{array}$ & t & sig \\
\hline & B & Std. Error & Beta & & \\
\hline \multirow{2}{*}{1} & (Constant) & 4,341 &, 392 & & 11,066 &, 000 \\
& Emotional Intelligence &,- 536 &, 111 &,- 389 & $-4,837$ &, 000 \\
\hline & Proactive Personality &,- 066 &, 100 &, 053 &,- 659 &, 511 \\
\hline
\end{tabular}

a. Dependent Variable: Burnout Level: $\mathrm{R}^{2}=, 172 ; \mathrm{S}, \mathrm{E},=, 47542 ; \mathrm{F}=16,563 ; \mathrm{p}=, 000$

As shown in Table 6, emotional intelligence seems to have a significant effect on burnout $\left(R^{2}=, 172\right.$, and $p$ $=, 000)$ as a result of the regression analysis performed. Also, Beta of Emotional Intelligence $(\beta=-.413$; sig $(p)$ $=.000$ ) is found. In social sciences these low values are accepted as normal measures. The results also supply the second hypothesis.

Table 7. The Moderating Role of Proactive Personality on the Relationship between Emotional Intelligence and Burnout

\begin{tabular}{cccccc}
\hline & Model & Unstd. Coefficients & $\begin{array}{c}\text { Std. } \\
\text { Coefficients }\end{array}$ & t & sig \\
\hline & B & S.E. & B & & \\
(Constant) & 6,617 & 3,377 & & 1,959 &, 052 \\
Emotional Intelligence & $-1,084$ &, 867 &,- 787 & $-1,250$ &, 213 \\
Proactive Personality &,- 591 &, 830 &,- 473 &,- 713 &, 477 \\
Emotional Intelligence * Proactive Personality &, 134 &, 211 &, 697 &, 638 &, 525 \\
\hline
\end{tabular}

a. Dependent Variable: Burnout Level: $\mathrm{R}^{2}=.175 ;$ S.E. $=.47630 ; \mathrm{F}=11.136 ; \mathrm{p}=.000$

As shown in Table 7, the moderating role of proactive personality on the relationship between emotional intelligence and burnout is analyzed. In moderating effect, there are two issues provided to do analysis (Erciş and Türk, 2016, p.15); while first of which is that there should not be any interaction among independent variable and moderating variable; second of which is that there is any change in R2 of the new model analysing the effect of independent and moderating variable together on dependent variable is significant. Although explaining power increases a little $\left(R^{2}=, 175\right)$ and the model is significant; because the () of EI*PA is not significant $(\mathrm{sig}=, 525)$ and coefficient of correlation between EI and PA $(r=, 442)$ causing multicollinearity problem; proactive personality does not seem to have a significant moderating role in this relationship. Thus the results do not supply the third hypothesis. 


\section{VI.Discussion and Conclusion}

In this research on academic staff working in public universities in Aegean and Central Anatolia regions, it was tried to determine whether the proactive personality is the moderator effect on the relationship between emotional intelligence and burnout syndrome. It is found that there is a negative significant relationship between emotional intelligence and burnout syndrome among academic staff. According to research findings, although the model was found to be meaningful, it was determined that proactive personality does not play a significant moderating role on the relationship between emotional intelligence and burnout syndrome. In Güllüce and İşcan (2010) research, it is found that there is a negative relationship between occupational burnout and sensory intelligence among the managers, as similar to our study. Similarly Herece and Şener (2017) found that there is positive significant effect of optimism and usage of emotions which are of the sub-dimensions of emotional intelligence on the personal success which is the subdimension of burnout syndrome. According to the results of the research conducted by Aslan and Özata (2008) in order to determine the relationship between emotional intelligence and burnout in health workers, it was concluded that four dimensions of emotional intelligence were negatively related to burnout's depersonalization dimension and positively related to personal success dimension. Konakay (2013), a study on the relationship between emotional intelligence factors and burnout factors in academicians: In the case of Kocaeli University, the study concluded that there was a negative relationship between emotional intelligence and burnout. Taşliyan et al. (2014) 's work to determine the relationship between Emotional Intelligence, Job Satisfaction and Burnout Levels of academicians in the work done to determine a significant relationship between emotional intelligence, job satisfaction and burnout, as well as some of the emotional intelligence factors demographic characteristics (gender, marital status and age) It has been found to be between. Between emotional evaluation and emotional exhaustion, moderate, negative; emotional management, empathic sensitivity, positive use of emotions and emotional exhaustion, low level, negative; Emotional assessment, emotional management, empathic sensitivity, positive use of emotions and personal achievement are low, positive; there is a low negative correlation between emotional assessment, emotional management, empathic sensitivity, positive use of emotions and depersonalization. It is seen that the study in question has a negative correlation with the emotional intelligence level that we have reached in our study.This study fills the gap in the national literature with the contribution by investigating the moderating effect of proactive personality on the relationship between emotional intelligence and burnout which has not been studied beforehand.

The most basic limitation is the inclusion of sampling in public universities only in the study; and the fact that the questionnaire is chosen as the data collection tool is the basic assumption that the participants are honest in the answers they give. Future studies may be contributed to the literature by expanding the sample, comparing public-private universities, or examining related phenomena in different sectors.

\section{References}

Akgül, A. and Çevik, O., İstatistiksel analiz teknikleri: spss'te işletme yönetimi uygulamaları, Emek Ofset, Ankara, 2005.

Akın, A., Abacı, R., Kaya, M., and Arıcı, N. (2011), “Kısaltılmış Proaktif Kişilik Ölçeği'nin (KPÖ) Türkçe formunun geçerlik ve güvenirliği", In ICES11 International Conference on Educational Sciences, June, 22-25.
Aktan,
M.
(2014),
“Akademisyenlerin
kişilik
özellikleri
nelerdir?"http://www.akademikpersonel.org/anasayfa/wp-

content/uploads/2014/01/K\%C4\%B0\%C5\%9E\%C4\%B0L\%C4\%B0K.jpg Erişim: 05.04.2018.

Alarcon, G. (2009), "Relationships between Personality Variables and Burnout: A Meta-Analysis", An International Journal of Work, Health \& Organizations, 23(3), 244-263.

Aslan, Ş. and Özata, M., (2008), “Duygusal zekâ ve tükenmişlik arasındaki ilişkilerin araştırılması: sağlık çalışanları örneği", Erciyes Üniversitesi İktisadi ve İdari Bilimler Fakültesi Dergisi, 0 (30), 77-97. 
M. Öneren - N. Çetiner - T. Arar - G. Yurdakul 11/1 (2019) 575-586

Bateman, Thomas S. and Crant, J. Michael, (1993), "The proaktive component of organizational behavior: A measure and correlates", Journal of Organizational Behavior, 14(2), 103-118.

Beierle, S. P., Kirkpatrick, B. A., Heidel, R. E., Russ, A., Ramshaw, B., McCallum, R. S., Lewis, J. M. (2018), "Evaluating and Exploring Variations in Surgical Resident Emotional Intelligence and Burnout", Journal of Surgical Education, Article In Press, 1-8.

Büyükgöze, H. and Gelbal, S., (2016), “Lisansüstü eğitime yönelik tutumda proaktif kişilik ve akademik kontrol odağının rolü", Eğitim Yönetimi Araştırmaları, (Ed: Beycioğlu K., Özer, N. Koşar, D. Şahin, İ.), Pegem Akademi, Ankara https://www.pegem.net/UserFiles/File/pdff.pdf Erişim:30.03.2018

Cambridge Learner's Dictionary English-Turkish, https://dictionary.cambridge.org/tr/s\%C3\%B6zl\%C3\%BCk/ingilizce-t\%C3\%BCrk\%C3\%A7e/proactive Erişim:11.03.2018

Candan, H. and İnce, M., (2014), "Mobbingden (bezdiri) tükenmişliğe giden yol: Çevre ve Şehircilik Bakanlığı çalışanları üzerinde bir araştırma", Çağ Üniversitesi Sosyal Bilimler Dergisi, 11(2), 56-85.

Candan, H., (2016), “Türkiye'de akademisyenlerin işe gömülmüşlükleri ile performans ve tükenmişlikleri arasındaki ilişkinin incelenmesine yönelik bir araştırma", IOSR Journal of Business and Management, 18(3), Ver.II, 68-80.

Chan, D. W., (2006), "Emotional Intelligence and Components of Burnout Among Chinese Secondary School Teachers in Hong Kong", Teaching and Teacher Education, 22(8), 1042-1054.

Cofer, K. D., Hollis, R. H., Goss, L., Morris, M. S., Porterfield, J. R., Chu, D. I., (2018), “Burnout is Associated with Emotional Intelligenece but not Traditional Job Performance Measurements in Surgical Residents", Jornal of Surgical Education, 75(5), 1171-1179.

Crant, J. M., (2000), "Proactive behavior in organizations", Journal of Management, June, 26(3), 435-462.

Çelik, E., and Topçuoğlu, P. (2017), “Proaktif kişiliğin öznel zindelik ile merak arasındaki ilişkide aracılık etkisi", Abant İzzet Baysal Üniversitesi Eğitim Fakültesi Dergisi, 17 (3), 1221-1240.

Çetin, F. and Basım, H.N. (2013), Örgütte bireysel farklılıkları, kişilik ve değerler, Ünsal Sığrı, Sait Gürbüz (Ed.), Örgütsal Davranış (s. 93-135), Beta Basım, İstanbul.

Çetin, F., and Varoğlu, A. K., (2009), "Özellikler bağlamında girişimcinin beş factor kişilik örüntüsü", Savunma Bilimleri Dergisi, 8(2), 51-66.

Erciş, A., Türk, B. (2016), “Etik Çerçevesinde Tüketim, Tüketici ve Çevre: Ekolojik Okuryazarlığın Moderatör Rolü", Çukurova Üniversitesi İ̈BF Dergisi, 20(2), 1-24.

Eren, N. Y. (2018), "Proaktif, Reaktif Olmak", Sektörel Yayın Dünyas1, http://www.sektorel.com/yazarlar/nilgun-yalim-eren/proaktif-reaktif-olmak Erişim: 05.04.2018.

Ergin, C. (1992), Doktor ve Hemşirelerde Tükenmişlik ve Maslach Tükenmişlik Ölçeği'nin Uyarlanması. 7. Ulusal Psikoloji Kongresi Bilimsel Çalışmaları, Hacettepe Üniversitesi, Ankara.

Frese, M., Kring, W., Soose, A., and Zempel, J., (1996), "Personal initiative at work: Differences between East and West German", Academy of Management Journal, 39(1), 37-63.

Freudenberger, H. J., (2012), "The issues of staff burnout in the rapeutic communities", Journal of $\begin{array}{lll}\text { Psychoactive } \quad \text { Drugs, } & \text { 247-251. }\end{array}$ https://www.tandfonline.com/doi/pdf/10.1080/02791072.1986.10472354?needAccess=true communities. J Psychoactive Drugs 1986Jul-Sep; 18(3): 247-51. Erişim:09.03.2018.

Goleman, D., (1998), Duygusal zekâ neden IQ'dan daha önemlidir, (B. S. Yüksel), Varlık Yayınları, İstanbul.

Goren, L. (2018), “Ten Strategies for Building Emotional Intelligence and Preventing Burnout", Access Link: www.aafp.org/fpm Access Date: 16.03.2019. 
M. Öneren - N. Çetiner - T. Arar - G. Yurdakul 11/1 (2019) 575-586

Göktepe, A. K.,\&Hiperlink, (. (Firm). 2016), “Tükenmişlik sendromu: tüketmeyin, tükenmeyin”, Nesil Yayın Grubu, İstanbul. http://web.a.ebscohost.com/ehost/ebookviewer/ebook?sid=dad96ab6-8dfa-462a-a446d519d7233945\%40sessionmgr4006\&vid=0\&format=EB Erişim:09.03.2018.

Güllüce, A.Ç. and İşcan, Ö. F., (2010), "Mesleki tükenmişlik ve duygusal zekâ arasındaki ilişki", Eskişehir Osmangazi Üniversitesi İ̈BF Dergisi, 5(2), 7-29.

Gürbüz, N, (2004), “Duygusal zekâ gelişiminde İngilizce öğretmeninin rolü”, XIII. Ulusal Eğitim Bilimleri Kurultayı, 6-9 Temmuz İnönü Üniversitesi Eğitim Fakültesi, Malatya, 1-7. https://www.pegem.net/dosyalar/dokuman/444.pdf Erişim:14.03.2018

Herece, F. and GökçeŞener, İ., (2017), “Duygusal zekâ ile tükenmişlik arasındaki ilişki: kamu sektöründe bir uygulama", Gazi İktisat ve İşletme Dergisi, 3(3), 38-54.

İraz, R. and Ganiyusufoğlu, A., (2011). “Örgütlerde mesleki tükenmişlik ve akademisyenler üzerinde bir uygulama", Sosyal Ekonomik Araştırmalar Dergisi, (21), 451-472.

Jafri, H., Dem, C., Choden, S. (2016), “Emotional Intelligence and Employee Creativity: Moderating Role of Proactive Personality and Organizational Climate", Business Perspectives and Research", 4(1), 54-66.

Karaçay, H. and Mıhçı, H. (1999), “Üniversite, Bilim Adamı ve Akademisyen: Kölelikten Özgürlüğe Doğru”, Toplum ve Hekim Dergisi, 14(4), 296-303.

Karadeniz, E. M. (2017), “Üstünlük vehmi ve örgütsel sinizm ilişkisi: akademisyenler üzerine bir çalışma”, (Yayınlanmamış Yüksek Lisans Tezi), Süleyman Demirel Üniversitesi, Sosyal Bilimler Enstitüsü, Isparta.

Karamustafa, E. Y., (2016), "The relationship between emotional intelligence and transformational \& transactional leadership styles and moderating role of gender: A study in Turkish energy sector", (Yayınlanmamış Yüksek Lisans Tezi), Yeditepe Üniversitesi, Sosyal Bilimler Enstitüsü, İstanbul.

Koçyiğit, M.,\& Hiperlink, (. (Firm). (2016). “Etkili iletişim ve duygusal zekâ". Eğitim Yayınevi, Konya. http://021090dfz.y.http.eds.b.ebscohost.com.proxy.kirikkale-

elibrary.com/eds/ebookviewer/ebook?sid=5d32113a-0d75-4017-9098-

c8c99a1afc6e\%40sessionmgr104\&vid=0\&format=EB Erişim: 10.03.2018.

Konakay, G., (2013), “Akademisyenlerde duygusal zekâ faktörlerinin tükenmişlik faktörleri ile ilişkisine yönelik bir araştırma: Kocaeli üniversitesi örneği", Dokuz Eylül Üniversitesi Sosyal Bilimler Enstitüsü Dergisi, 15 (1), 121-144.

Lee, S. M. and Peterson, S. J., (2000), "Culture, entrepreneuria lorientation, and global competitiveness", Journal of World Business, 35 (4), 401-416.

Lumpkin, G.T. and Dess, G.G., (1996), "Clarifying the entrepreneurial orientation construct and linking it to performance", The Academy of Management Review, Academy of Management, 21(1), 135-172.

Maboçoğlu, F. (2006), “Duygusal zekâ ve duygusal zekânın gelişimine katkıda bulunan etkenler", (Yayınlanmamış Yüksek Lisans Tezi), Ankara Üniversitesi, Sosyal Bilimler Enstitüsü, Ankara.

Mete, F. and Akpınar, K. D., (2013), “Dil öğretimi ve duygusal zekâ”, 21. Yüzyılda Eğitim ve Toplum, Cilt: 2, Sayı:5, 73-85.

Ortaş, İ., (2004), “Öğretim üyesi ya da bilim insanı kimdir?”, Pivolka, Y11:3 Sayı:12, 11-16, http://www.elyadal.org/pivolka/12/PiVOLKA_12_03.pdf Erişim: 05.04.2018

Öztürk, A., (2006), “Okul öncesi öğretmenlerinin duygusal zekâ yetenekleri iş doyumları ve tükenmişlik düzeylerinin bazı değişkenler açısından karşılaştırmalı olarak incelenmesi", (Yayınlanmamış Yüksek Lisans Tezi), Selçuk Üniversitesi, Sosyal Bilimler Enstitüsü, Konya.

Pérez-Fuentes, M., Molero-Jurado, M., Gazques-Linares, J., Simon-Marquez, M. (2019), “Analysis of Burnout Predictors in Nursing: Risk and Protective Psychological Factors", The European Journal of Psychology Applied to Legal Context, 11(1), 33-40. 
M. Öneren - N. Çetiner - T. Arar - G. Yurdakul 11/1 (2019) 575-586

Platsidou, M. (2010), "Trait Emotional Intelligence of Greek Special Education Teachers in Relation to Burnout and Job Satisfaction", School Psychology International, 31(1), 60-76.

Salovey, P. and Grewal, D., (2005), "The science of emotional intelligence", Current Directions in Psychological Science 14(6), 281-285http://0211m0e55.y.http.journals.sagepub.com.proxy.kirikkaleelibrary.com/doi/pdf/10.1111/j.0963-7214.2005.00381.x Erişim: 14.03.2018.

Salovey, P. and Mayer J. D., (1990), “Emotional intelligence", Cognition and Personality, 9(3), 185211.http://0211m0e55.y.http.journals.sagepub.com.proxy.kirikkaleelibrary.com/doi/pdf/10.2190/DUGG-P24E-52WK-6CDG Erişim: 12.03.2018.

Schwartzhoffer, R. V., (2009), Psychology of burnout: predictors and coping mechanisms, Nova Science Publishers, Inc., New York. http://proxy.kirikkaleelibrary.com/MuseSessionID=0211t0em2/MuseProtocol=http/MuseHost=web.b.ebscohost.com/MuseP ath/ehost/ebookviewer/ebook/bmxlYmtfXzM1OTAxNF9fQU41?sid=f74c6d3d-ed44-4607-8612c742227a4863@pdc-v-sessmgr01\&vid=4\&format=EB\&rid=6 Erişim:16.03.2018.

Somuncuoğlu, D. (2005), "Duygusal zekâ yeterliliklerinin kuramsal çerçevesi ve eğitimdeki rolü”, Atatürk Üniversitesi Kazım Karabekir Eğitim Fakültesi Dergisi, Sayı:11, 269-293.

Taşlıyan, M., Hırlak, B. and Çiftçi, G.E., (2014), "Akademisyenlerin Duygusal Zekâ, İş Tatmini ve Tükenmişlik Düzeyleri Arasındaki İlişki", İşletme Araştırmaları Dergisi, 6(3), 63-80.

Uncuoğlu Yolcu, İ. and Çakmak, A. F., (2017), "Proaktif kişilik ile proaktif çalışma davranışı ilişkisi üzerinde psikolojik güçlendirmenin etkisi", Uluslararası Yönetim İktisat ve İşletme Dergisi, 13(2), 425-438.

Weisinger, H. (1998), “İş yaşamında duygusal zekâ”, (N. Süleymangil), MNS Yayıncılık, İstanbul.

Yürür, Ş. (2011), “Öğrenilmiş güçlülük, kıdem ve medeni durumun duygusal tükenmedeki rolü: kaynakların korunması teorisi kapsamında bir analiz", Atatürk Üniversitesi İktisadi ve İdari Bilimler Dergisi, 25 (1), 107-126. 